\title{
HEPATOPROTECTIVE ACTIVITY OF FRUIT EXTRACTS OF PHYLLANTHUS ACIDUS LINN. IN CARBON TETRACHLORIDE INDUCED HEPATOTOXIC MODEL IN ALBINO RATS
}

\author{
Lakshman Das ${ }^{1}$, Ranjib Ghosh², Prithul Bhattacharjee 3 \\ ${ }^{1}$ Assistant Professor, Department of Pharmacology, Tripura Medical College \& Dr. B.R.A.M Teaching Hospital, Hapania, Agartala. \\ ${ }^{2}$ Associate Professor, Department of Pharmacology, Tripura Medical College \& Dr. B.R.A.M Teaching Hospital, Hapania, Agartala. \\ ${ }^{3}$ Assistant Professor, Department of Pharmacology, Tripura Medical College \& Dr. B.R.A.M Teaching Hospital, Hapania, Agartala.
}

\section{ABSTRACT}

\section{BACKGROUND}

Phyllanthus acidus Linn. (PA) plant is widely used for treating jaundice in rural areas of North Eastern States of India, but there is lack of scientific evidence regarding its usage in liver disorders, although experiments with shrubs and herbs belonging to same species have been performed.

\begin{abstract}
AIMS
To study the effect of aqueous fruit extract of Phyllanthus acidus Linn. (PA) in carbon tetrachloride $\left(\mathrm{CCl}_{4}\right)$ induced hepatotoxicity in albino rats.

\section{SETTING AND DESIGN}

Twenty four healthy albino rats of either sex weighing 100-125gm were utilized for the study. They were randomized into 4 groups (Normal, Control, Standard and Test) of 6 animals in each group.
\end{abstract}

\section{METHODS AND MATERIAL}

Hepatic injury was induced in all groups (Except normal group) by i.p. injection of $1: 1 \mathrm{v} / \mathrm{v} \mathrm{CCl} 4$ in olive oil (1 $\mathrm{ml} / \mathrm{kg}$ body weight) for 7 days simultaneously with control, standard and test drugs.

\section{STATISTICAL ANALYSIS}

Results were analysed by ANOVA followed by student ' $t$ ' test.

\section{RESULTS AND CONCLUSION}

The administration of $\mathrm{CCl}_{4}$ to the animals resulted in a marked increase in hepatic markers. Animals treated with PA exhibited a significant decrease in the hepatic markers in comparison to the control group. The present study shows that the aqueous fruit extracts of Phyllanthus acidus Linn. Has significant hepatoprotective activity in $\mathrm{CCl}_{4}$ induced hepatotoxic model in albino rats.

\section{KEYWORDS}

Hepatoprotective, Phyllanthus Acidus, Carbon Tetrachloride.

HOW TO CITE THIS ARTICLE: Lakshman Das, Ranjib Ghosh, Prithul Bhattacharjee. "Hepatoprotective Activity of Fruit Extracts of Phyllanthus Acidus Linn. in Carbon Tetrachloride Induced Hepatotoxic Model in Albino Rats." Journal of Evolution of Medical and Dental Sciences 2015; Vol. 4, Issue 100, December 14; Page: 16517-16519, DOI: 10.14260/jemds/2015/2457

\section{INTRODUCTION}

The liver is the key organ regulating homeostasis in the body, which is involved in almost all the biochemical pathways related to growth and fight against disease.[1] In spite of tremendous scientific advancement in the field of hepatology in recent years, liver problems are on the rise. Jaundice and hepatitis are two major hepatic disorders that account for a high death rate. $[2,3]$

Phyllanthus acidus Linn. (PA) belongs to the family: Phyllanthaceae (Division: Magnoliophyta, Class: Magnoliophyta, Order: Malpighiales). They are native of South America; cultivated widely in tropical regions. The plant is intermediary between shrubs and tree, reaching 2 to 9 meters $\left(6 \frac{1}{2}\right.$ to 30 feet $)$ in height and profusely branching.

Financial or Other, Competing Interest: None.

Submission 24-11-2015, Peer Review 25-11-2015,

Acceptance 05-12-2015, Published 12-12-2015.

Corresponding Author:

Dr. Lakshman Das,

Assistant Professor,

Department of Pharmacology,

Tripura Medical College \& Dr. B.R.A.M Teaching Hospital,

Hapania, Agartala.

E-mail:doctorldas@gmail.com

DOI:10.14260/jemds/2015/2457
The branches bear alternate leaves that are ovate with pointed ends. The leaves are $2-7.5 \mathrm{~cm}$ long and thin. They are green and smooth on the upper side and blue-green on the underside. The fruit makes a delicious preserve; green leaves are used as a vegetable. The bark is used for tanning. ${ }^{[4]}$ The plant is widely used for treating jaundice in rural areas of North Eastern States of India, but there is lack of scientific evidence regarding its usage in liver disorders, although experiments with shrubs and herbs belonging to same species have been performed. Hence, the present study was aimed to investigate the hepatoprotective activity of fruit extract of $\mathrm{P}$. acidus in $\mathrm{CCl}_{4}$ induced hepatotoxic model in albino rats.

\section{MATERIALS AND METHODS Plant Materials and Extract \\ The fruits of P. acidus were collected during the month of June of 2014 from the localities of Agartala, Tripura and were authenticated by Dr. R. K. Sinha, Department of Botany, Tripura University. The material was air dried under shade and powdered mechanically. About $350 \mathrm{gm}$ of powdered material was boiled with $1000 \mathrm{ml}$ of distilled water for $30 \mathrm{~min}$ and filtered through Whattman no.1 filter paper to obtain PA.}


The extract was concentrated and dried using water bath. ${ }^{[5]}$ The yield was $0.5 \%$. All the experiments are done in the Department of Pharmacology, Tripura Medical College and Dr. B.R.A.M. Teaching Hospital, Agartala.

\section{Animal}

Albino rats of either sex weighing 100-125gm were obtained from Animal House, Tripura Medical College and Dr. B.R.A.M. Teaching Hospital, Hapania, Agartala. They were maintained at standard laboratory conditions and fed with standard rat diet and water ad-libitum during the period of experiment. They were habituated to laboratory conditions for 24 hours prior to the experimental procedure to minimize any stress.

\section{Induction of Hepatotoxicity}

Hepatic injury was induced by intra-peritoneal injection of $1: 1 \mathrm{v} / \mathrm{v} \mathrm{CCl}{ }_{4}$ in olive oil at a dose of $1 \mathrm{ml} / \mathrm{kg} /$ day for 7 days.[6]

\section{EVALUATION OF HEPATOPROTECTIVE ACTIVITY}

Twenty four healthy albino rats of either sex were randomized into 4 groups of 6 animals in each group. They are as follows:

\section{GROUP- A (NORMAL)}

Normal saline- $1 \mathrm{ml} / \mathrm{kg} /$ day intra-peritoneally for 7 days.

II. GROUP- B (CONTROL)

$\mathrm{CCl}_{4}$ and normal saline- $5 \mathrm{ml} / \mathrm{kg} /$ day orally for 7 days.

III. GROUP- C (STANDARD)

$\mathrm{CCl}_{4}$ and Silymarin $100 \mathrm{mg} / \mathrm{kg} /$ day orally for 7 days.

\section{GROUP- D (TEST)}

$\mathrm{CCl}_{4}$ and $\mathrm{PA} 500 \mathrm{mg} / \mathrm{kg} /$ day orally for 7 days.

Control, Standard and Test drugs were administered orally with the help of stomach tube once daily for 7 days. Silymarin was chosen as standard and used at a dose of $100 \mathrm{mg} / \mathrm{kg} /$ day. ${ }^{[6]}$
No adverse effect or mortality was detected in the albino rats with oral PA $(2 \mathrm{gm} / \mathrm{kg})$ observed for 24 hours during preliminary toxicity test. The dose of the standard drug was calculated from human dose by extrapolation based on surface area.[7]

\section{ASSESSMENT OF HEPATOPROTECTIVE ACTIVITY}

After 7 days, blood samples from each rat were collected from orbital sinus with the help of capillary tube.[8] Serum was separated by centrifugation. The serum was used for the assay of hepatic markers viz., Aspartate transaminase (SGOT), Alanine transaminase (SGPT), alkaline phosphatase (ALP) and serum bilirubin by kinetic methods in a semiautoanalyser.[9]

\section{Ethics}

The study was conducted with the approval of Institutional Animal Ethical Committee.

\section{Statistical Analysis}

Results were analysed by ANOVA followed by student ' $t$ ' test.

\section{RESULT}

The administration of $\mathrm{CCl}_{4}$ to the animals resulted in a marked increase in total bilirubin, serum SGOT, SGPT and ALP levels in control group indicating liver injury caused by $\mathrm{CCl}_{4}$. This finding is in accordance with that of another study.[5] Animals treated with PA showed a significant lower levels in the hepatic markers in comparison to the control group $(\mathrm{p}<0.001)$. The prevention of raise of hepatic markers by the standard drug was more significant in comparison to control $(p<0.001)$. PA was as effective as standard in preventing the increase of the hepatic markers $(p>0.5)$. (Results are shown in Table-1 and Figure-1).

\begin{tabular}{|c|c|c|c|c|}
\hline GROUP & $\begin{array}{c}\text { SGOT } \\
\text { (IU/L) }\end{array}$ & $\begin{array}{c}\text { SGPT } \\
\text { (IU/L) }\end{array}$ & $\begin{array}{c}\text { ALP } \\
\text { (IU/L) }\end{array}$ & $\begin{array}{c}\text { Total Biluribin } \\
\text { (IU/L) }\end{array}$ \\
\hline Normal $(\mathrm{NS})$ & $148.5 \pm 6.090$ & $98 \pm 7.183$ & $168 \pm 6.928$ & $0.42 \pm 0.0424$ \\
\hline Control $\left(\mathrm{CCl}_{4}\right)$ & $544 \pm 10.373$ & $188 \pm 12.987$ & $684.5 \pm 7.661$ & $2.51 \pm 0.2024$ \\
\hline $\begin{array}{c}\text { Standard }\left(\mathrm{CCl}_{4}\right)+ \\
\text { silymarin) }\end{array}$ & $194^{*} \pm 7.823$ & $128^{*} \pm 8.124$ & $178^{*} \pm 8.342$ & $0.58^{*} \pm 0.0834$ \\
\hline Test $\left(\mathrm{CCl}_{4}+\mathrm{PA}\right)$. & $197^{*} \# \pm 8.694$ & $104^{* \wedge} \pm 8.438$ & $208^{* \wedge} \pm 9.338$ & $0.82^{* \wedge} \pm 0.0933$ \\
\hline Table 1: Effect of Phyllanthus acidus Linn. on hepatic markers in CCI $_{4}$ induced \\
hepatotoxicity in albino rats
\end{tabular}

One way F 2868.63829 .0231009382 .7736

ANOVA df 3, $203,203,203,20$

$P$ value $<0.01<0.01<0.01<0.01$

Values are expressed as mean \pm standard deviation.

$* \mathrm{p}<0.001$ as compared to control value.

\# $\mathrm{p}>0.5$ as compared to standard value.

$\wedge \mathrm{p}<0.001$ as compared to control value.

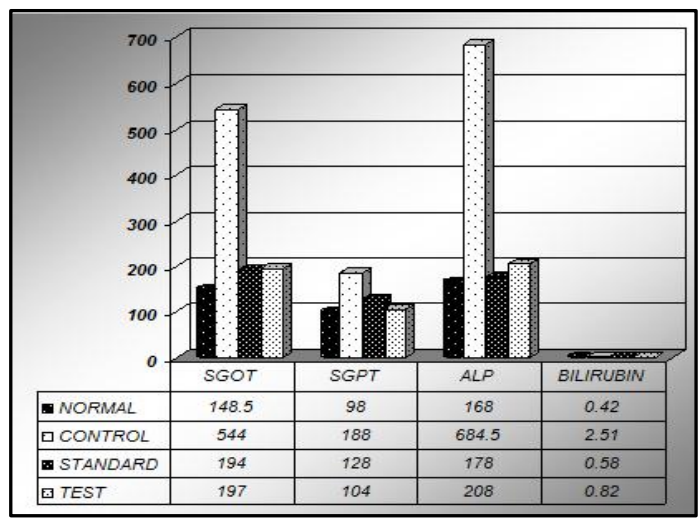

Fig. 1: Effect of Phyllanthus acidus Linn. On hepatic markers in $\mathrm{CCl}_{4}$ induced hepatotoxicity in albino rats

\section{DISCUSSION}

The liver can be injured by many chemicals and drugs. $\mathrm{CCl}_{4}$ is widely used as hepatotoxin in experimental studies. The $\mathrm{CCl}_{4}$ is biotransformed by cytochrome p450 to produce the trichloromethyl free radicals, which in turn covalently binds to cell membranes and organelles to elicit lipid peroxidation. This causes loss of integrity of cell membranes and damage of hepatic tissue.[10] During hepatic damage, cellular enzymes like SGOT, SGPT, ALP present in the liver cells leak into the serum resulting in increased concentrations.[11] In the present study $\mathrm{CCl}_{4}$ treated animals there is significant increase in SGOT, SGPT, ALP and bilirubin level in comparison to normal group. PA significantly prevents the increase of these hepatic markers due to $\mathrm{CCl}_{4}$. The prevention of the increase in hepatic markers due to $\mathrm{CCl}_{4}$ by $\mathrm{PA}$ is comparable to that of standard drug silymarin. The component(s) of the extract responsible for this effect however was not investigated. Further investigations are needed for identification of the active compounds of PA responsible for hepatoprotective activity. 


\section{CONCLUSION}

The present study shows that the aqueous fruit extract of Phyllanthus acidus Linn. Has significant hepatoprotective activity in carbon tetrachloride induced hepatotoxicity in albino rats.

\section{ACKNOWLEDGEMENT}

We are thankful to Micro Labs Company for providing free sample of silymarin and also thankful to the staffs of Department of Pharmacology for providing technical help.

\section{REFERENCES}

1. Vipul G, Nilesh P, Rao Venkat N, Nanda Kumar K, Gouda TS, Shalam Md, Shanta Kumar SM. Hepatoprotective activity of alcoholic and aqueous extracts of leaves of Tylophora indica (Linn.) in rats. Indian J Pharmacol 2007;39:43-7.

2. Pang S, Xin X, Stpierre MV. Determinants of metabolic disposition. Ann Rev Pharmacol Toxicol 1992;32:625-6.

3. Ross MH, Romrell LJ, Kaye GI. Histology a text and atlas. Wiliam and Wilkins: Baltimore; 1996.

4. Deb DB. The flora of Tripura State. Vol. 1. Today and Tomorrow's Printers and Publishers; 1981:345-46.

5. Mankani KL, Krishna V, Manjunatha BK, Vidya SM, Jagadeesh Singh SD, Manohara YN, Raheman Anees UR, Avinash KR. Evaluation of hepatoprotective activity of stem bark of Pterocarpus marsupium Roxb. Indian J Pharmacol 2005;37:165-68.
6. Mangathayaru K, Grace XF, Bhabani M, Meignanam E, Karna SLR, Kumar DP. Effect of Leucas aspera on hepatotoxicity in rats.

Indian J Pharmacol 2005;37: -68.

7. Sahu N, Das S. Hepatoprotective activity of Eugenia jumbos Linn. on albino rats. Indian J Pharmacol 2006;38:574.

8. Ghosh MN. Guide to drug dose in loboratory animals. Fundamentals of experimental pharmacology. $2^{\text {nd }}$ ed. Kolkata: Scientific Book Agency; 1984.

9. Van Herck H, Baumanas V, Van der CNR, Hesp APM, Meijer GW, Van TG, Walvoort HC and Beynen AC: Histological changes in the orbital region of rats after orbital puncture, Laboratory animals; 26:53-58, 1992.

10. Manjunatha BK. Hepatoprotective activity of Pterocarpus santalinus l.f., an endangered medicinal plant. Indian J Pharmacol 2006;38:25-8.

11. Recknagel RO, Glende EA, Hruszkewyez AM. Free radicals in Biology. In: Proyer EA, editor. Vol. 3. Academic Press; 1976. p. 97.

12. Deb AC. Fundamentals of biochemistry. $7^{\text {th }}$ ed. New Central Book Agency: Kolkata; 1998. 